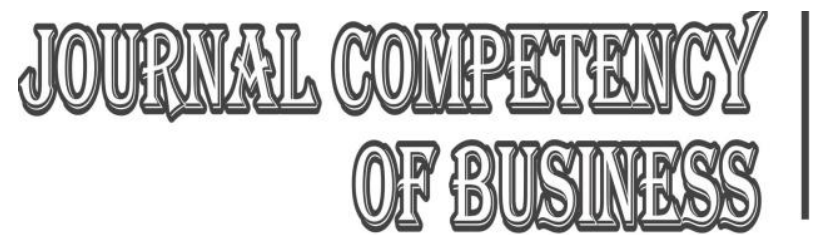

\title{
KEPUTUSAN PEMBELIAN MAHASISWA PADA PRODUK ONLINE SHOP SHOPEE DAN FAKTOR PENENTUNYA
}

\author{
Heru Ependi ${ }^{1}$, Reza Widhar Pahlevi ${ }^{2}$ \\ ${ }^{1}$ Prodi Manajemen, Fakultas Ekonomi, Universitas Cokroaminoto Yogyakarta \\ ${ }^{2}$ Prodi Kewirausahaan, Fakultas Ekonomi dan Sosial, Universitas Amikom Yogyakarta \\ ${ }^{1}$ heruependi1998@gmail.com ; ${ }^{2}$ rezawp@amikom.ac.id
}

\begin{abstract}
Abstrak
Tujuan penelitian ini adalah untuk mengetahui faktor apa saja penentu keputusan pembelian online konsumen Shopee serta bagaimana proses keputusan pembelian online konsumen Shopee. Pendekatan penelitian yang digunakan yaitu pendekatan deskriptif kualitatif. Penelitian terkait dengan faktor keputusan pembelian online konsumen di Shopee, maka obyek yang akan diteliti adalah konsumen yang menggunakan aplikasi Shopee. Pada situasi sosial atau objek penelitian dengan objek penelitian ini yaitu Mahasiswa Fakultas Ekonomi Universitas Cokroaminoto Yogyakarta, yang aktif menggunakan aplikasi Shopee sebagai tempat berbelanja online, dan yang dianggap memenuhi atau mengetahui kriteria penelitian. Berdasarkan hasil pembahasan bahwa promosi yang diterapkan toko e-commerce Shopee, seperti halnya penerapan promosi diskon, promosi gratis ongkos kirim, harga, kualitas produk dan kepercayaan yang diberikan oleh perusahan Shopee, mempengaruhi terhadap keputusan pembelian online konsumen di Shopee selanjutnya proses keputusan pembelian konsumen secara online yang didahului oleh, pengenalan masalah, pencarian informasi, evaluasi alternatif, keputusan pembelian, perilaku pasca pembelian,dipengaruhi oleh banyak faktor. Faktor ini dapat dikelompokkan menjadi faktor internal, yaitu psikologi konsumen, dan faktor eksternal, yang terdiri dari lingkungan sosial budaya masyarakat, stimulan pemasaran, dan sistem kontrol vendor yang meliputi efisiensi untuk pencarian waktu harga bersaing dan kualitas baik.
\end{abstract}

\section{Kata kunci: Keputusan Pembelian Online, E-Commerce, Harga, Promosi dan Kualitas}

\begin{abstract}
The purpose of this study is to find out what factors determine online consumer purchasing decisions at Shopee and how the online consumer purchasing decisions process at Shopee. The research approach used is a qualitative descriptive approach. Research related to consumer online purchasing decision factors at Shopee, the object to be studied is consumers who use the Shopee application. In social situations or research objects, the object of this research is the students of the Faculty of Economics, Cokroaminoto University, Yogyakarta, who actively use the Shopee application as a
\end{abstract}


place to shop online, and who are considered to meet or know the research criteria. Based on the results of the discussion that the promotions implemented in the Shopee ecommerce store, such as the application of discount promotions, free shipping promotions, prices, product quality and trust given by the Shopee company, affect consumers' online purchasing decisions at Shopee and then the online consumer decision process. preceded by, problem recognition, information search, evaluation of alternatives, purchase decisions, post-purchase behavior, influenced by many factors. These factors can be internal factors, namely consumer psychology, and external factors, which consist of the socio-cultural environment of the community, marketing stimuli, and vendor control systems which include time efficiency in seeking competitive prices and good quality.

\section{Keywords: Online Purchase Decision, E-Commerce, Price, Promotion and Quality}

\section{PENDAHULUAN}

Era modern saat ini, internet menjadi semakin canggih dan terus berkembang, perkembangan internet yang sangat pesat ini menyebabkan internet sebagai media informasi yang tidak bisa lepas dari kehidupan mahasiswa saat ini. Perkembangan teknologi saat ini sangat menguntungkan bagi banyak orang karena bisa memberikan banyak manfaat. Seperti halnya jika dulu internet hanya digunakan untuk mencari data atau mengirim informasi, tetapi sekarang internet dapat digunakan untuk banyak hal, salah satunya untuk menjalankan usaha ataupun berbelanja (Setiaman, 2019). Meskipun pemasaran melalui internet sudah berkembang, namun tidak semua online shop menggunakan komunikasi bisnis dengan cara yang sama dan tepat sasaran. Pemasaran melalui media online kenyatannya cukup sulit dalam menembus pasar. Hal ini disebabkan karena begitu banyak perbedaan konsumen, mulai dari cara berbelanja, mengapresiasikan suatu produk, dan perbedaan budaya, perkembangan teknologi saat ini menjadi tantangan tersendirI bagi e-commerce untuk bersaing menarik hati konsumen (Yanis, 2020).

Berdasarkan hasil penelitian yang dilakukan Harahap dan Amanah (2018) pada perilaku belanja online atau pembelian online, menyatakan bahwa kepercayaan, harga, kenyamanan, merupakan faktor yang paling utama mempengaruhi keputusan pembelian konsumen. Selanjutnya keamanan, kualitas produk, dan perilaku konsumtif juga mempengaruhi pembelian online. Konsumen dengan mempersepsikan bahwa transaksi secara online mudah dilakukan dan tidak mengandung unsur penipuan, maka konsumen akan 
Fakultas Ekonomi, Universitas Cokroaminoto Yogyakarta

tertarik untuk berbelanja secara online, informasi berpengaruh langsung terhadap keputusan pembelian secara online.

Berbelanja secara online, informasi seputar produk, harga dan lainnya informasikan ditoko online sehingga konsumen yang akan melakukan pembelian lebih mudah dalam mencari produk. Hal ini lebih mudah diketahui oleh konsumen tanpa harus mendatangi toko secara langung, penggunaan media sosial tidak dapat memediasi persepsi, informasi, dan motivasi terhadap keputusan pembelian secara online. Artinya penggunaan media sosial tidak ikut mempengaruhi persepsi konsumen dalam menentukan keputusan pembelian secara online. Disamping itu informasi tanpa penggunaan media sosialpun, masih bisa diketahui lewat orang lain. Artinya informasi yang konsumen, dapatkan sendiri dimedia sosial tidak menjamin konsumen langsung tertarik untuk berbelanja secara online.

Sebelum konsumen memutuskan membeli suatu produk, biasanya ada beberapa faktor yang menjadi pertimbangan seperti kepercayaan. Kendala yang biasanya dihadapi oleh konsumen adalah adanya suatu keraguan dalam berbelanja online, karena masih banyaknya pembeli yang menganggap bahwa belanja lewat online terlalu beresiko, yang dimana mereka khawatir tidak akan mendapatkan produk dengan kualitas yang tepat, dan dapat diantarkan tepat waktu serta ke tempat yang tepat. Tetapi pada dasarnya kepercayaan berkaitan dengan keyakinan, bahwa sesuatu itu benar atau salah atas dasar bukti, sugesti, otoritas, pengalaman dan intuisi (Rafidah, 2017).

Sedangkan penelitian Sitorus dan Utami (2017) mengatakan bahwa promosi merupakan salah satu variabel penting dilaksanakan oleh perusahaan dalam memasarkan produkdan jasa, kegiatan promosi bukan saja berfungsi sebagai alat komuniiasi antara perusahaan dengan konsumen, melainkan juga sebagai alat untuk mempengaruhi konsumen dalaam kegiatan pembelian atau penggunaan sesuai dengan keinginan dan kebutuhan, salah satu promosi yang sering kali dipakai oleh perusahaan e-commerce dalam mempengaruhi perilaku konsumen dalam pembelian antara lain seperti diskon, gratis ongkos kirim, promosi dan kualitas layanan yang baik, terbukti efektif dalam mempengaruhi niat beli online konsumen . 
Fakultas Ekonomi, Universitas Cokroaminoto Yogyakarta

Penelitian ini mengambil objek online shop "Shopee". Shopee memiliki program flash sale, dimana penawaran produk-produk tertentu yang sudah disetujui oleh penjual dapat dijual dengan harga lebih murah dan dalam waktu yang terbatas bagi konsumen, program flash sale ini sangat menguntungkan untuk dapat meningkatkan portofolio penjualan, dan mendapatkan peringkat best seller dalam produk yang mampu terjual sesuai target yang ditentukan. Program flash sale ini dapat mempengaruhi keputusan pembelian konsumen, karena waktu yang mendesak dalam penjualan, serta harga yang di tawarkan tentunya lebih murah (Widianto dan Octaviani, 2020). Penetapan diskon atau potongan harga dalam bisnis penjualan online suatu hal yang sangat penting dan harus dipertimbangkan oleh penjual, karena setiap penentuan harga akan mengakibatkan tingkat permintaan konsumen yang berbeda, penetapan diskon ini terbukti sangat efektif dalam meningkatan keputusan pembelian online konsumen. Selain diskon, kualitas layanan yang baik yang diberikan oleh penjual, juga menjadi pertimbangan yang dapat mempengaruhi konsumen dalam memutuskan pembelian. pelayanan yang baik yang diberikan oleh penjual, akan membuat konsumen merasa puas. Hal ini tidak menutup kemungkinan bahwa jika konsumen merasa puas, maka konsumen akan loyal terhadap toko tersebut (Setyarko, 2016). Berdasarkan latar belakang dapat diambil rumusan masalah: faktor apa saja penentu keputusan pembelian online konsumen di Shopee serta bagaimana proses keputusan pembelian online konsumen di Shopee.

\section{KAJIAN PUSTAKA}

\section{Keputusan Pembelian Online}

Menurut Kotler dan Armstrong (2011) keputusan pembelian merupakan perilaku konsumen untuk melakukan pembelian atau transaksi. Konsumen seringkali dihadapkan pada beberapa pilihan dalam membeli suatu barang atau produk, keputusan pembelian adalah perilaku yang timbul karena adanya rangsangan atau hubungan dari pihak lain. Pengambilan keputusan merupakan suatu kegiatan individu yang secara langsung terlibat dalam mendapatkan dan mempergunakan barang yang ditawarkan. Keputusan pembelian yang dilakukan oleh konsumen seringkali dihadapkan pada beberapa alternatif produk yang ada. Sebelum konsumen memutuskan untuk mengambil keputusan pembelian, dan lebih memilih 
Fakultas Ekonomi, Universitas Cokroaminoto Yogyakarta

berbelanja secara online dibandingkan berbelanja secara tradisional, tentunya ada faktorfaktor yang menjadi alasan konsumen dan pertimbangan konsumen, dalam menentukan keputusan pembelian online, dari hasil penelitian didapat beberapa alasan konsumen memilih berbelanja secara online antara lain:

1. Kualitas layanan

Kualitas layanan merupakan, tingkat kondisi baik atau buruknya sajian yang diberikan penjual dalam rangka memuaskan konsumen dengan memberikan atau menyampaikan, keinginan atau permintaan melebihi apa yang diharapkan konsumen (Tjiptono, 2011). Menurut Tjiptono (2011) mengemukakan bahwa kualitas pelayanan adalah, upaya pemenuhan kebutuhan dan keinginan konsumen serta ketepatan penyampaiannya dalam menimbangi harapan konsumennya. Kualitas layanan yang baik diberikan perusahaan kepada pelanggan merupakan hal yang sangat penting. Transaksi jual beli online membuat konsumen, membutuhkan pelayanan yang baik seperti kemudahan dalam, proses transaksi online, sehingga konsumen akan merasa terdorong untuk melakukan keputusan pembelian. Penelitian yang dilakukan Setyarko (2016) menyatakan bahwa kualitas layanan berpengaruh secara signifikan terhadap keputusan pembelian produk secara online.

\section{Promosi}

Promosi merupakan bagian dari kegiatan pemasaraan dikenal sebagai unsur dari bauran pemasaran (marketing mix). Promosi adalah sarana dimana perusahaan berusaha untuk membujuk, menginformasikan dan mengingatkan konsumen baik secara langsung maupun tidak langsung, tentang produk dan merek yang mereka jual (Shakti dan Zuliarni, 2019). Menurut Kotler dan Armstrong (2008), promosi adalah pedoman khusus untuk melakukan periklanan, promosi penjualan, hubungan masyarakat, penjualan pribadi, dan pemasaran langsung yang digunakan untuk mengkomunikasikan dan menciptakan hubungan dengan pelanggan. Aktivitas promosi yang dilakukan oleh e-commerce untuk meningkatkan jumlah pengujung atau pembeli online adalah dengan melakukan promosi dalam bentuk flash sale pada waktu-waktu tertentu. Flash sale ini merupakan aktivitas promosi yang dilakukan dalam waktu yang singkat dengan memberikan diskon harga, cashback atau gratis ongkos kirim bagi pembeli yang berbelanja secara online. Aktivitas promosi dengan metode seperti flash sale. terbukti sangat berpengaruh terhadap keputusan pembelian 
Fakultas Ekonomi, Universitas Cokroaminoto Yogyakarta

konsumen, terkadang konsumen memiliki persepsi yang berbeda terhadap promosi yang dilakukan oleh pemasar. Oleh karena itu, peneliti ingin menganalisis persepsi pelanggan terhadap flash sale belanja online dan bagaimana pula pengaruhnya terhadap keputusan pembelian konsumen. (Devica, 2020).

\section{Harga Produk}

Menurut Kotler dan Armstrong (2016) harga adalah sejumlah uang yang di bebankan atas suatu barang atau jasa atau jumlah dari nilai uang yang ditukar konsumen atas manfaatmanfaat karena memiliki atau menggunakan produk atau jasa tersebut. Penetapan harga yang tepat akan menciptakan pengaruh konsumen untuk berbelanja, oleh sebab itu harga dapat mempengaruhi seseorang untuk berbelanja dan mempengaruhi keputusan pembelian. Kotler dan Amstrong (2016) harga merupakan bagian penentu yang ada dalam suatu penjualan, dan setiap produk yang dijual pasti memiliki harga yang dicantumkan. Harga merupakan sejumlah uang yang dikeluarkan oleh konsumen untuk sebuah produk dan jasa atau sejumlah nilai yang ditukarkan oleh konsumen untuk memperoleh manfaat atau kepemilikan atau penggunaan atas sebuah produk atau jasa. Fungsi harga yang dapat membantu para konsumen untuk memutuskan cara mendapatkan manfaat tertinggi yang diharapkan berdasarkan kemampuan membelinya. Dengan adanya harga yang di tetapkan akan membantu pembeli untuk dapat memutuskan cara mengalokasikan pembeliannya. Konsumen yang akan belanja online akan membandingkan harga dari berbagai alternatif yang tersedia, kemudian konsumen yang akan membeli dapat mengambil keputusan berbelanja, dengan harga yang telah ditetapakan penjual.

\section{Kepercayaan Konsumen}

Sebelum konsumen memutuskan membeli suatu produk, biasanya ada beberapa faktor yang menjadi pertimbangan seperti kepercayaan. Kendala yang biasanya dihadapi oleh online konsumen adalah adanya suatu keraguan dalam berbelanja online, karena masih banyaknya pembeli yang menganggap bahwa belanja lewat online terlalu beresiko, yang dimana mereka khawatir tidak akan mendapatkan produk dengan kualitas yang tepat, dan dapat diantarkan tepat waktu serta ke tempat yang tepat. Tetapi pada dasarnya kepercayaan berkaitan dengan keyakinan, bahwa sesuatu itu benar atau salah atas dasar bukti, sugesti, otoritas, pengalaman dan intuisi (Rafidah, 2017). 
Fakultas Ekonomi, Universitas Cokroaminoto Yogyakarta

\section{E-Commerce}

Shopee merupakan market place jual beli online yang banyak diminati oleh kalangan mahasiswa saat ini, yang senang mengunakan media sosial sebagai tempat untuk berbelanja. Menurut Barkatullah dan Prasetyo (2005) e-commerce atau lebih dikenal dengan e-com, dapat diartikan sebagai suatu cara berbelanja atau berdagang secara online atau direct selling yang memanfaatkan fasilitas internet, dimana terdapat website yang menyediakan layanan get and delivere-commerce adalah kegiatan-kegiatan bisnis yang menyangkut konsumen, manufaktur, service providers dan pedagang perantara dengan menggunakan jaringanjaringan komputer yaitu internet. E-commerce adalah transaksi jual beli secara elektronik melalui media internet, tanpa harus tatap muka antara penjual dan pembeli. Belanja online atau e-commerce adalah sebuah proses transaksi yang dilakukan melalui media atau perantara, yaitu berupa situs-situs jual beli online ataupun jejaring sosial yang menyediakan barang atau jasa yang diperjualbelikan. Kini belanja online telah menjadi sebuah kebiasaan bagi sebagian orang, dikarenakan lebih mudah, danlebih praktis, orang-orang banyak beranggapan bahwa belanja online adalah salah satu sarana untuk mencari barang-barang yang diperlukan seperti kebutuhan sehari-hari, dan sebagainya (Harahap, 2018).

\section{METODE PENELITIAN}

Pendekatan penelitian yang digunakan yaitu pendekatan deskriptif kualitatif. Menurut Moleong (2012) pendekatan deskriptif kualitatif yaitu, pendekatan penelitian dimana datadata yang dikumpulkan berupa kata-kata, gambar-gambar dan bukan angka. Data-data tersebut dapat diperoleh dari hasil wawancara, catatan lapangan, foto, vidio dan dokumentasi pribadi, untuk memperoleh pengetahuan secara mendalam studi kasus dapat diperoleh, dengan mencari informan yang yang paham tentang suatu obyek yang akan diteliti, seperti halnya jika penelitian terkait dengan faktor keputusan pembelian online konsumen di Shopee, maka obyek yang akan diteliti adalah konsumen yang menggunakan aplikasi Shopee.

Pada situasi sosial atau objek penelitian ini, penelitian dapat mengamati secara mendalam aktivitas orang-orangyangada pada tempat tertentu. Situasi sosial tersebut dapat dinyatakan sebagai objek penelitian yang ingin diketahui apa yang terjadi didalamnya Adapun yang menjadi objek dalam penelitian ini yaitu Mahasiswa Fakultas Ekonomi 
Fakultas Ekonomi, Universitas Cokroaminoto Yogyakarta

Universitas Cokroaminoto Yogyakarta, yang aktif menggunakan aplikasi Shopee sebagai tempat berbelanja online, dan yang dianggap memenuhi atau mengetahui kriteria penelitian. Menurut Moleong (2012) diperlukan pertimbangan-pertimbangan untuk memilih dan menentukan sampel, peneliti harus memilih sampel yang dianggap mengetahui permasalahan yang terjadi, sekaligus apa yang kita harapkan di dalam penelitian. Adapun pertimbangan sampel tersebut antara lain bahwa, subjek yang terpilih dipandang mengetahui adanya permasalahan yang terjadi. Peneliti menggunakan teknik purposive sampling yaitu melakukan pertimbangan-pertimbangan sebelum melakukan penelitian dan wawancara kepada informan, agar suatu penelitian yang dilakukan mendapatkan informasi yang akurat dan kredibel terhadap suatu penelitian yang dilakukan. Memilih informan yang benar-benar aktif berbelanja online di Shopee.

\section{HASIL DAN PEMBAHASAN}

Shopee menawarkan berbagai macam kebutuhan pria dan wanita, yang menyesuaikan gaya hidup di Indonesia, sesuatu yang menarik dari Shopee adalah barang yang ditawarkan merupakan, barang yang sedang trendy pada saat ini sehingga, produk yang ditawarkan pada shopee terus mengikuti kebutuhan, gaya hidup pria dan wanita yang semakin modern. Barang yang ditawarkan oleh Shopee berbagai macam seperti pakaian wanita, pakaian pria, barang elektronik, alat rumah tangga, kebutuhan olahraga dan lain sebagainya.Dalam menghadapi persaingan e-commerce di Indonesia, Shopee memberikan platform belanja online yang mengusung konsep sosial, dimana konsumen ini tidak hanya berfokus pada jual beli saja, tetapi juga bisa berinteraksi sesama konsumen lewat fitur pesan instan secara langsung, dilengkapi dengan metode pembayaran yang aman dengan menggunakan kode verifikasi.

\section{Faktor Penentu Keputusan Pembelian Online Konsumen Shopee}

Keputusan pembelian merupakan tindakan yang dilakukan seseorang dalam memilih atau membeli sesuatu dengan kriteria tertentu, keputusan pembelian dapat dipengaruhi oleh rasa suka atau kepuasan seseorang terhadap barang yang dibeli karena sesuai dengan kebutuhan dan keinginan konsumen, keputusan pembelian dapat dipengaruhi dari beberapa alternatif seperti, promosi sepertibanyakannya promo-promo atau diskon, pelayanan, harga produk, kepercayaan konsumen, dan kualitas produk. Beberapa faktor-faktor yang diungkapkan oleh 
informan 1 mengenai alasan mereka memilih berbelanja online di Shopee dan memutuskan pembelian yaitu:

"Harga dan kualitas produk menjadi faktor utama yang saya pertimbangkan dalam berbelanja online di Shopee dankepercayaan, saya dari dulu sering berbelanja di Shopee karena harga-harga nya lebih murah dibandingkan dengan toko e-commerce lainnya dan penggunaan aplikasinya juga lebih mudah, serta banyaknya diskon-diskon yang dilakukan perusahaan Shopee, tetapi diskon yang terlampau kecil tidak mempengaruhi niat berbelanja saya. Menurut saya jika diskonnya terlampau kecil buat apa dipertimbangkan yang penting harganya terjangkau dan kualitas nya bagus, saya memilih berbelanja online karena karena harganya lebih murah dibandingkan kita berbelanja secara tradisional, jika berbelanja secara tradisional kan harus ke tokonya langsung dan tidak banyak pilihanpilihan produk, saya di Shopee sering berbelanja atribut-atribut seperti baju, pertama saya mengenal Shopee itu dari iklan-iklan di tv dan teman saya, pelayanan yang baik dari penjul juga mempengaruhi pembelian apalagi ketika kita menanyakan sesuatu terkait produk yang ingin di beli melalui fitur chat dan langsung dibalas oleh toko tersebut, promosi yang diterapkan Shopee sangat mempengaruhi pembelian saya, di Shopee kan biasanya ada promosi terkait kualitas produk dan merek, diskon potongan harga dan gratis ongkir, bagi saya itu sangat mempengaruhi pembelian saya pribadi”.

Informan mengaku bahwa ia sudah sangat lama berbelnja online di Shopee, ia sangat senang berbelanja di Shopee karena bisa dilakukan dari rumah dengan menggunakan media sosial. Harga yang murah, kualitas yang baik menjadi faktor utamanaya memilih berbelanja di Shopee, serta banyaknya diskon-diskon dan tingkat kepercayaan sangat mempengaruhinya dalam berbelanja. Akan tetapi diskon yang terlalu kecil kurang mempengaruhi niat berbelanjanya. Kualitas produk memiliki suatu ketertarikan bagi konsumen dalam mengelola hubungan yang baik dengan perusahaan penyedia produk apabila perusahaan ingin mempertahankan keunggulan kompetitifnya dalam pasar. Berdasarkan hasil analisis data yang diperoleh penulis melalui wawancara kepada informan 2. Secara simultan promosi, layanan, kualitas produk, harga, kepercayaan, serta potongan harga dan memiliki berpengaruh signifikan terhadap keputusan pembelian online pada e-commerce Shopee.

"Awalnya saya memilih berbelanja online di Shopee karena bisa berbelanja dari rumah menggunakan handphone kan lebih peraktis, jika dibandingkan saya harus ke toko langsung, belum biaya ongkos mau ke tokonya, dan kalau kita berbelanja online di Shopee kan lebih banyak pilihan dan motif-motif produknya. Harga produk diShopee lebih terjangkau dari pada toko e-commerce lainnya seperti,Lazada, Bukalapak, dan Tokopedia, yang membuat saya berbelanja di Shopee, penggunaan aplikasinya juga lebih mudah dari toko e-commerce lainya, kualitas produknya juga bagus-bagus. Ongkirnya juga lebih murah dibandingkan toko lain. Saya berbelanja online di Shopee sudah sangat lama, dan

E-ISSN: 2777-1156 
Fakultas Ekonomi, Universitas Cokroaminoto Yogyakarta

selama saya berbelanja di Shopee tidak pernah ada kasus penipuan jadi kepercayaan dan faktor keamanan berbelanja juga menjadi pertimbangan saya untuk berbelanja, ketika saya ingin berbelanja online saya pasti menggunakan Shopee, di Shopee juga banyak diskondiskon dan potongan harga yang membuat saya suka berbelanja diShopee. Bagi saya penerapan gratis ongkir yang di lakukan Shopee sangat mempengaruhi pemblein saya, kalau gratis ongkir nya mahal lebih baik cari toko e-commerce lain yang memberikan gratis ongkos pengiriman, diskon juga mempengaruhi pembelin saya, dengan adanya diskon kan belanja nya bisa lebih banyak, jika tidak ada diskon saya kurang tertarik untuk membeli, pelayanan yg baik juga sangat mempengaruhi pembelian saya, promosi yang dilakukan Shopee juga sangat mempengaruhi niat berbelanja saya, Shopee kan biasanya sering mempromisikan produk yang dijual, mulai dari potongan harga, gratis ongkos kirim dengan pembelian tertentu, dan lain-lainnya".

Sejalan dengan apa yang tuturkan oleh Sampouwi dan Wulandari (2020) potongan harga, bebas biaya ongkos kirim, dan beragam promosi seperti cashback dan flash sale menjadi faktor utama penelitian ini. Pasalnya sebagian besar konsumen mengakui bahwa segala hal yang di indikasikan membuat harga komoditas lebih murah, sehingga membuat mereka semakin meliriknya. Selain dari implikasi tren untuk membawapara konsumen pada keputusan pembelian, yang semakin kuat, mereka memilih Shopee karena satu alasan besar yaitu, harga yang terjangkau. Potongan harga pun membuat konsumen tertarik untuk melihat dan memantaukomoditas yang di inginkan. Belum lagi jika potongan harga tersebut masuk dalam kategori flash sale, yang artinya potongan harga yang diberikan memiliki harga yang jauh lebih murah daripada harga di pasaran. Fenomena demikian membentuk suatu budaya baru, yang bagi peneliti yaitu sikap impulsif dalam belanja. Selanjutnya informan 3 menuturkan bahwa faktor yang mendorong ia memutuskan berbelanja di Shopee:

"Awalnya saya mengenal aplikasi Shopee dari iklan di televisi, dari situ saya tertarik dengan Shopee. Saya memilih berbelanja di Shopee pertama, karena bisa kapan saja dan dimana saja, kan sistemnyapembeliannya online, jadi lebih praktis, dan kita tidak mesti datang langsung ke tempat penjualan, penggunaan aplikasinya juga mudah, pengalaman saya berbelanja online harganya lebih murah dari pada berbelanja secara tradisional, harga sangat mepengaruhi pembelian saya, dan di Shopee juga banyak diskondiskon, kualitas produknya juga bagus-bagus, tetapi harga tidak menjadi faktor utama yag saya kedepankan, yang penting bagi saya kualitas produknya bagus, kan biasanya jika harga murah mencerminkan kualitas produnya juga kurang bagus,faktor pertama saya memutuskan pembelian pertama harga, kualitas diskoin-diskon dan kepercayaan, biasanya yang sering saya beli di Shopee itu seperti baju, shampo, bedak dan handbody, proses keputusan pembelian saya ketika saya ingin membeli suatu produk di Shopee itu pertama, mencari informasi tentang produk tersebut, dan kualitas produknya agar ketika sudah 
Fakultas Ekonomi, Universitas Cokroaminoto Yogyakarta

membeli tidak merasa kecewa, biasanya saya ketika ingin membeli produk sedangkan saya tidak terlalu paham dengan kualitas dan merek produknya, sebelum membeli itu saya nanya-nanya dulu ke teman-teman yang mungkin pernah, contohnya ketika saya ingin membeli handphone atau skincar jadi sebelum saya membeli saya nanya-nanya ke teman, dan mencari informasi-informasi terkait produknya bagus atau tidak."

Dapat disimpulkan dari pernyatan informan diatas, bahawa media saat ini sangat mempermudah mereka dalam melakukan pembelian produk secara online. Mahasiswa menganggap berbelanja online sekarang sudah menjadi kebutuhan mereka,karena lebih praktis dan tidak menyita waktu, serta pembayaranya pun bisa dilakukan setelah barang yang dibeli sampai ketangan konsumen, selain itu disebutkan harga produk, berbelanja online lebih murah dan banyak diskon-diskon, dan varian produk-produk lebih banyak sehingga konsumen lebih leluasa dalam memilih produk-produk yang diinginkan. Kepercayaan pembeli sebagai kunci terpenting karena aktivitas bidang usaha yang dijalankan adalah melalui online, penjual dan pembeli tidak berhadapansecara langsung,dari sisi keamanan dalam bertransaksi, Shopee menjamin dengan sistem garansi dan juga menyediakan rekening bersama untuk melindungi konsumen agar tidak tertipu.

Selanjutnya, berdasarkan hasil wawancara yang dituturkan oleh Informan 4 bahwa:

"Gratis ongkos kirim yang diterapkan Shopee bagi saya sangat berpengaruh, kalau ada gratis ongkos kirim saya sangat berantusias membeli produk, penerapan diskon dari perusahaan Shopee juga mempengaruhi pembelian saya kalau diskonnya besar, ya saya tertarik untuk membeli produk dari toko tersebut, pelayanan yang baik juga mempengaruhi pembelian saya, karena dengan pelayanan yang baik, jika kita ingin menanyakan sesuiatu terkait produk, kita lebih paham dan tidak merasa menyesal setelah melakukan pembelian"

Sejalan dengan pendapat Setiaman (2019) bahwa penetapan harga dalam bisnis $e$ commerce merupakan suatu hal yang sangat penting dan harus dipertimbangkan oleh penjual, karena setiap penentuan harga akan mengakibatkan tingkat permintaan konsumen yang berbeda.Dari hasil penelitian bahwa media sosial, harga, kepercayaan, layanan, promo, dan kualitas produk, berpengaruh positif dan signifikan terhadap keputusan pembelian,kualitas layanan yang baik juga menjadi pertimbangan yang dapat mempengaruhi keputusan pembelian. Semakin baik kualitas layanan yang diberikan oleh perusahaan maka akan membuat konsumen merasa puas.Tidak hanya harga dan kualitas layanan, Komunikasi juga 
Fakultas Ekonomi, Universitas Cokroaminoto Yogyakarta

memegang peran penting dalam kegiatan pemasaran untuk meningkatkan penjualan.

Komunikasi sangat membantu konsumen dalam mengambil keputusan pembelian.

\section{Proses Keputusan Pembelian Online Konsumen Shopee}

Menurut Firmansyah (2019) perilaku pembelian online adalah proses membeli produk atau jasa melalui media internet. Proses pembelian online memiliki langkah yang berbeda seperti perilaku pembelian fisik. Kekhasan dari proses membeli melalui media internet adalah ketika konsumen yang berpotensial menggunakan internet dan mencari-cari informasi yang berkaitan dengan barang atau jasa yang mereka butuhkan. Firmansyah (2019) menjelaskan bahwa proses pengambilan keputusan merupakan proses psikologis dasar yang memainkan peranan penting dalam memahami bagaimana konsumen secara aktual mengambil keputusan pembelian. Proses pengambilan keputusan diawali dengan adanya kebutuhan yang berusaha untuk dipenuhi. Pemenuhan kebutuhan ini terkait dengan beberapa alternatif sehingga perlu dilakukan evaluasi yang bertujuan untuk memperoleh alternatif terbaik dari persepsi konsumen, di dalam proses membandingkan ini, konsumen memerlukan informasi, yang jumlah dan tingkat kepentingannya tergantung dari kebutuhan konsumen serta situasi yang dihadapinya. Keputusan pembelian akan dilakukan dengan menggunakan kaidah menyeimbangkan sisi positif dengan sisi negatif suatu merek (compensatory decision rule) ataupun mencari solusi terbaik dari perspektif konsumen (non-compensatory decision rule), yang setelah konsumsi akan dievaluasi kembali. Dari hasil yang diperoleh peneliti kepada informan, tahapan-tahapan atau proses mereka dalam melakukan pembelian online di Shopee antara lain:

"Awalnya saya mengenal aplikasi Shopee itu dari sumber informasi media sosial, sebelum saya berbelanja produk yang ingin saya beli, saya mencari tahu dulu informasiinformasi produk yang akan saya beli melalui media, dan bertanya kepada teman, terus melihat berapa banyak orang yang berbelanja di toko tersebut dan riview pembelinya, jadi misalnya saya ingin membeli jam tangan atau sepatu, saya bertanya terlebih dahulu sebelum membeli kepada teman saya yang juga pengguna aplikasi Shopee, yang pernah berbelanja di toko tersebut, apakah produk-produknya bagus atau tidak". "Ketika saya ingin membeli suatu barang yang saya butuhkan, saya mencari informasi langsung ke toko yang bersangkutan, soalnya di informasi lapak tersebut kan ada terjual berapa produknya, dan penilaian dari konsumen yang pernah berbelanja disana, kalau saya pribadi ketika saya ingin membeli produk, tetapi saya tidak paham dengan merek dan 
Fakultas Ekonomi, Universitas Cokroaminoto Yogyakarta

kualitas dari produk tersebut, saya menanyakan langsung ke toko penjual lewat fitur chat yang ada di Shopee, jika tidak ada tanggapan dari penjual, baru saya mencari informasi dari google atau menanyakan kepada teman yang lebih tahu dan berpengalaman."

Begitu banyaknya kategori produk yang dicantumkan dalam situs, membuat banyak pilihan juga bagi konsumen untuk memilih atau mencari produk-produk yang diminatinya. Kategori yang begitu banyak akan menarik minat konsumen untuk melakukan pencarian dan melakukan transaksi jual-beli, sehingga kepercayaan mengenai keamanan dalam transaksi, ketepatan pengiriman barang serta mengatasi keluhan konsumen harus diperhatikan oleh Shopee. Hal tersebut juga menjadi perhatian bagi konsumen mengingat transaksi yang dilakukan dalam belanja online antara penjual dan pembeli tidak melakukan tatap muka sehingga kredibilitas situs menjadi salah satu hal yang juga diperhatikan oleh konsumen sehingga transaksi jual-beli dapat terus dilakukan. Hal tersebut juga menjadi perhatian bagi konsumen mengingat transaksi yangdilakukan dalam belanja online antara penjual dan pembeli tidak melakukan tatap mukasehingga kredibilitas situs menjadi salah satu hal yang juga diperhatikan oleh konsumen sehingga transaksi jual-beli dapat terus dilakukan. Oleh sebab itu, penelitian ini akan fokus terhadap bagaimana proses pengambilan keputusan dalam situs belanja online Shopee sebagai pemenuhan kebutuhan konsumen.

"Sebelum saya membeli produk di Shopee itu saya mencari informasi-informasi dulu terkait barang yang ingin dibeli, melihat reting tokonya bagus atau tidak, sebelum saya memutuskan untuk membeli produk ditoko yang bersangkutan, saya menanyakan terlebih dahulu terkait produk yang ingin saya beli kepada temen yang pernah berbelanja produk tersebut, kalau begitu kan kita ada gambaranlah sebelum membeli produk tesebut."

Berdasarkan hasil wawancara penulis dengan informan, sebelum mereka melakukan pembelian ada beberapa faktor yang mereka lalui dalam proses/tahapan mereka dalam membeli. Sejalan dengan pendapatnya Mustika dan Astiti (2017) ada lima tahap yang dilalui oleh konsumen dalam proses keputusan pembelian, yaitu: 
Fakultas Ekonomi, Universitas Cokroaminoto Yogyakarta

Proses pembelian dimulai dari pembeli mengenali masalah atau kebutuhan konsumen. Pengenalan masalah merupakan tahapan pengambilan keputusan yang ditandai dengan adanya masalah kebutuhan. Pengenalan kebutuhan ini diperlihatkan melalui kebutuhan pada kebutuhan sehari-hari. Dapat disimpulkan bahwa konsumen akhirnya menjatuhkan pilihan keputusan pembelian pada Shopee karena beragam kebutuhan, seperti kebutuhan pribadi, kebutuhan pekerjaan, dan kebutuhan mendadak yang sangat diperlukan.

\section{b. Pencarian Informasi}

Setelah melihat pada analisis mengenai pengenalan kebutuhan konsumen, peneliti melanjutkan analisis pada bagian pencarian informasi. Hasil penelitian dari penjabaran pada proses ini sangat beragam, sebab referensi atau sumber yang menginisiasi informasi dapat ditemukan di mana saja. Menurut Kotler dan Armstrong (2011) dijelaskan bahwa pencarian informasi adalah kondisi ketika seseorang yang sudah mengetahui apa yang menjadi kebutuhan kemudian mencari informasi secara aktif mengenai produk untuk memenuhi kebutuhannya. Pencarian informasi ini dapat dilakukan melalui beberapa sumber, seperti sumber pribadi keluarga, teman sumber komersial iklan, kemasan, situs web sumber publik media massa, pencarian internet, dan sumber pengalaman penanganan, pemeriksaan, pemakaian produk konsumen akan terdorong untuk mencari informasi yang lebih banyak untuk mengetahui kebutuhannya. Ketika niat konsumen muncul secara utuh dalam membeli barang, proses pencarian informasi mulai dilakukan.Berdasarkan hasil penelitian setidaknya ditemukan ada empat unsur yang menjadi komunikator atas informasi ini, yakni: iklan, dan akun onlineshop, keluarga, teman,dan facebook.

c. Evaluasi Alternatif

Konsumen mengolah informasi dari berbagai merek yang bersaing dan membuat penilaian akhir tentang kebutuhan yang akan dibeli. Konsumen cenderung membeli secara langsung (impulsive) dari pada mengevaluasi pilihan serta mempersempit 
Fakultas Ekonomi, Universitas Cokroaminoto Yogyakarta

pilihan pada alternative yang ada. Hal ini terjadi karena konsumen membeli sesuatu tanpa mengetahui barang apa yang akan dibeli sebelumnya. Ini dikarenakan konsumen mudah tertarik dengan gambar serta tampilan yang disediakan oleh toko online. Sedangkan untuk konsumen yang melakukan evaluasi alternatif, memang sudah memiliki keinginan/rencana awal untuk membeli sesuatu. Dengan adanya rencana pembelian suatu barang tersebut membuat konsumen melakukan evaluasi terhadap barang maupun tempat/toko online yang akan dipilih.Evaluasi alternatif terdiri dari dua tahap, yaitu menetapkan tujuan pembelian dan menilai serta mengadakan seleksi terhadap alternatif pembelian berdasarkan tujuan pembeliannya. Setelah konsumen mengumpulkan informasi mengenai jawaban alternatif terhadap suatu kebutuhan, maka konsumen akan mengevaluasi pilihan dan menyederhanakan pilihan pada alternatif yang diinginkan (Firmansyah, 2019).

\section{d. Keputusan Pembelian}

Setelah tahap evaluasi, konsumen membuat daftar tabel atas merek-merek yang ada di dalam pilihannya. Konsumen juga membuat keputusan akhir untuk membeli merek yang paling disukai untuk memenuhi kebutuhannya.Keputusan membeli pada konsumen terjadi setelah melakukan pemilihan alternatif maupun tidak. Terdapat perbedaan waktu yang dibutuhkan antara membuat keputusan pembelian dengan menciptakan pembelian yang aktual. Proses bagaimana konsumen membuat keputusan membeli sebagian besar berasal dari media sosial atau media internet/online. Hal itu terjadi adanya intensitas konsumen dalam mengakses media online. Tanpa adanya pertimbangan konsumen mudah memutuskan untuk membeli suatu barang hanya dengan alasan estetika barang atau gambar yang menarik. Sehingga dapat disimpulkan bahwa perilaku belanja online pada sebagian konsumen terjadi secara impulsif. Adapun barang-barang yang dibeli konsumen sebagian besar berupa produk yang bersifat sebagai penunjang penampilan. 


\section{e. Perilaku Pasca Pembelian}

Setelah pembelian, apabila konsumen merasa senang dan puas akan barang atau merek tersebut, biasanya mereka akan kembali memesan barang lainnya untuk memenuhi kebutuhannya.Pasca pembelian secara online konsumen mengalami pengalaman yang menyenangkan dan juga tidak menyenangkan. Sebagian besar konsumen merasa puas karena beberapa keuntungan yang didapat melalui belanja online seperti: prosesnya cepat, mudah, barang yang ditawarkan bervariasi. Dari beberapa keuntungan tersebut responden juga mengalami hal yang kurang memuaskan ketika belanja secara online. Hal ini tidak membuat konsumen berhenti karena sebagin besar konsumen termotivasi membeli produk secara online karena proses belanja online itu sendiri, bukan kepada produk yang akan dibeli.Bedasarkan penjelasan hasil diatas, dapat ditarik simpulan bahwa tahapan yang muncul atau terjadi pada kenyataannya adalah berawal dari penggunaan media sosial yang tinggi . Pada pemaparan diatas dapat dilihat bahwa proses pengambilan keputusan dalam perilaku belanja online melalui lima tahapan. Tahapan pertama adalah mengenali masalah, pencarian informasi, evaluasi alternatif, keputusan pembelian, dan perilaku pasca pembelian (Mustika dan Astiti, 2017).

\section{KESIMPULAN DAN SARAN}

Berdasarkan hasil pembahasan dapat disimpulkan bahwa promosi yang diterapkan toko e-commerce Shopee, seperti halnya penerapan promosi diskon, promosi gratis ongkos kirim, harga, kualitas produk dan kepercayaan yang diberikan oleh perusahan Shopee, mempengaruhi terhadap keputusan pembelian online konsumen di Shopee.

Proses keputusan pembelian konsumen secara online yang didahului oleh pengenalan masalah, pencarian informasi, evaluasi alternatif, keputusan pembelian, perilaku pasca pembelian dan dipengaruhi oleh banyak faktor. Faktor ini dapat dikelompokkan menjadi faktor internal, yaitu psikologi konsumen, dan faktor eksternal, yang terdiri dari lingkungan 
Fakultas Ekonomi, Universitas Cokroaminoto Yogyakarta sosial budaya masyarakat, stimuli pemasaran, dan sistem kontrol vendor yang meliputi efisiensi untuk pencarian waktu harga bersaing dan kualitas baik .

Penelitian ini tidak terlepas dari beberapa keterbatasan dan kelemahan. Berdasarkan hasil analisis maka saran yang dapat diberikan adalah bagi mahasiswa, terutama mahasiswa Fakultas Ekonomi Universitas Cokroaminoto Yogyakarta yang sering berbelanja online di Shopee, sebaiknya sebelum melakukan transaksi atau pembelian online di e-commerce Shopee, memperhatikan ulasan dari konsumen yang pernah melakukan pembelian ditoko Shopee tersebut, untuk menghindari ketidaksesuaian barang yang dipesan,dan sebaikanya lebih teliti lagi dalam berbelanja agar produk atau barang yang dibeli sesuai dengan apa yang diinginkan, serta menghindari transaksi diluar aplikasi Shopee, untuk menghindari penipuan; Selanjutnya bagi peneliti selanjutnya, diharapkan untuk lebih rinci dan luas lagi dalam menganalisis tentang faktor penentu keputusan pembelian online konsumen Shopee, dan proses keputusan pembelian konsumen, agar mendapatkan data yang akurat serta mendapatkan inti masalah yang mempengaruhi konsumen memilih berbelanja online di Shopee.

\section{DAFTAR PUSTAKA}

Barkatullah, A.H. dan Prasetyo, T. (2005) . Bisnis E-Commerce Studi Sistem Keamanan dan Hukum di Indonesia. Yogyakarta: Pustaka Pelajar

Boyd, Harper W., Orville C. Walker dan Jean- Claude Larrenche. (2000). Manajemen Pemasaran : Suatu Pendekatan Strategis dengan Orientasi Global. Jilid 2. Edisi Kedua. Alih Bahasa : Imam Nurmawan. Jakarta : Penerbit Erlangga

Firmansyah, M A., (2019) Perilaku Konsumen Sikap dan Pemasaran. Penerbit Qiara Media. Yogyakarta

Harahap, D. A. dan Amanah, D. (2018) Perilaku Belanja Online di Indonesia : Studi Kasus. Jurnal Riset Manajemen Sains Indonesia (JRMSI) Vol 9. No. 2, 2018

Inas Rafidah (2017). Keamanan Kemudahan Dan Kepercayaan Terhadap Keputusan Pembelian Secara Online Di Lazada. Jurnal Ilmu dan Riset Manajemen Volume 6, Nomor 2, Februari 2017 ISSN : 2461-0593

Kotler dan Amstrong. (2010). Prinsip-prinsip Pemasaran Jilid 1 \& 2 Edisi 12. Jakarta: Gramedia

Liang, T. P dan Lai, H. J. (2002). Effect of store design on consumer purchases: An empirical study of on-line bookstores. Information and Management, 39 (6), 431444.https://doi.org/10.1016/S0378-7206(01)00129-X

Mursid, M., (2010) Manajemen Pemasaran Jakarta: Bumi Aksara 
Fakultas Ekonomi, Universitas Cokroaminoto Yogyakarta

Nurlitasari, Tika. (2012). Pengaruh Multi Atribut Terhadap Preferensi Belanja Online Produk Pakaian Di Kalangan Mahasiswa Universitas Muhammadiyah Purworejo. Jurnal Segmen.Vol.8. No.2

Samuri, V. I.F., Soegoto, A,S., dan Woran, D., (2018) Studi Deskriptif Motivasi Belanja Hedonis Pada Konsumen Toko Online Shopee. Jurnal EMBA.Vol.6 No.4

Selvi,E dan Utari, D.(2020). Strategi Komunikasi Pemasaran Dalam Memanfaatkan Aplikasi Shopee Pada Akun Subur Batik. Jurnal Penelitian Manajemen Volume,2 Nomor 1, April 2020

Setiaman, D. (2019) Pengaruh,Kualitas Layanan Dan Word Of Mouth Terhadap Keputusan Pembelian Online Shopee.Co.id. Jurnal Ilmu dan Riset Manajemen. Volume 8. No3

Setyarko. (2016). Analisis Pesepsi Harga, Promosi, Kualitas Layanan dan Kemudahan Penggunanaan Terhadap Keputusan Pembelian Produk Secara Online. Jurnal Ekonomika dan Manajemen.

Sumarwan, U. (2014). Model Keputusan Konsumen. In Perilaku konsumen (1st ed., pp. 141). Universitas Terbuka

Suyanto, M. (2003). Strategi Periklanan pada E-Commerce Perusahaan Top Dunia. Yogyakarta: Andi

Tulanggow, S.G., Tumbal, T. M dan Walangitan, O., Pengaruh Promosi dan Harga Terhadap Keputusan Pada Pembelian PT. Shopee International Indonesia di Kota Manado. Jurnal Administrasi Bisnis (JAB) Vol. 9. No. 3, 2019

Yanis, F., (2020) Strategi Komunikasi Bisnis Online Shop "Shoppe" Dalam Meningkatkan Penjualan.Jurnal Abiwara.Vol. 1, No. 2, Maret 2020 